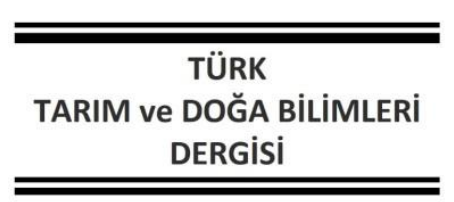

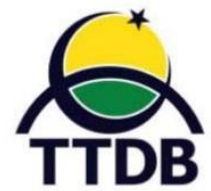

www.dergipark.gov.tr/turkjans

Araştırma Makalesi

\title{
Identification and phylogenetic differences of newly isolated Streptomyces sp
}

\author{
Şükrü ÖNALAN ${ }^{1 *}$, Hamdullah SEÇKiN²
}

${ }^{1}$ Van Yuzuncu Yil University, Fisheries Faculty, Department of Fish Diseases, Van, Turkey

${ }^{2}$ Van Yuzuncu Yil University, Fisheries Faculty, Van Health Services Vocational School, Van, Turkey

*Sorumlu Yazar: sukruonalan@yyu.edu.tr

Received: 04.03.2021 Received in revised: 03.05.2021 Accepted: 30.06.2021

\begin{abstract}
Antimicrobial resistance and antibiotic use is a global health crisis today. Streptomyces is the source of most antimicrobials. Therefore, the similarities and differences within the species of Streptomyces are of great importance. In this study, isolation and identification of 3 different Streptomyces species isolated from sediment from the Dicle region were performed. Then, 16S rRNA gene sequence was obtained and the similarities and differences between species were revealed. As a result of the study, bacteria contained colorimetric differences, when looking at the spore chain morphology in the SEM image, a knobby structure was formed, 16S rRNA sequences longer than $1000 \mathrm{bp}$ and in the phylogenetic tree created, 1 isolate was closely similar to the sequences obtained from GenBank $(99 \%<$ ), other It was observed that the two isolates differed. 2 different Streptomyces isolates obtained in line with these results are important in terms of antibiotic production and different resistance conditions in subsequent studies.
\end{abstract}

Key words: Real-Time PCR, Sequencing, 16S rRNA gene, Streptomyces sp.

\begin{abstract}
İzole edilen yeni Streptomyces türlerinin tanımlanması ve filogenetik farklılıkları
Öz

Antimikrobiyal direnç ve antibiyotik kullanımı günümüzde küresel bir sağılı krizidir. Streptomyces türleri antimikrobiyallarin çoğunun kaynağıdır. Bundan ötürü Streptomyceslerin tür içi benzerlik ve farklılıkları büyük öneme sahiptir. Bu çalışmada Dicle bölgesinden sedimentten izole edilen 3 farklı Streptomyces türünün izolasyon ve identifikasyonu gerçekleştirilmiştir. Ardından 165 rRNA gen sekansı elde edilerek türler arası benzerlik ve farklııkları ortaya konulmuştur. Çalışma sonucunda bakterilerin clorometrik farklııklar içerdiği, SEM görüntüsünde spor zincir morfolojisine bakıldığında budaklı (knobby) bir yapının oluştuğu, 16S rRNA 1000 bp den uzun sekans hizalamasında ve oluşturulan filogenetik ağaçta GenBank'tan elde edilen sekanslar ile 1 izolatın yakın benzerlikte olduğu (\% $99<$ ), diğer iki izolatın ise farklılık gösterdiği gözlenmiştir. Bu sonuçlar doğrultusunda elde edilen 2 farklı Streptomyces izolatının sonraki çalışmalarda antibiyotik üretimlerinin ve farklı direnç gösterme durumları yönünden önem arz etmektedir.
\end{abstract}

Anahtar kelimeler: Real-Time PCR, Sekanslama, 16S rRNA geni, Streptomyces sp.

\section{Introduction}

The large number of bioactive compounds produced by Streptomyces species makes the diagnosis of these bacteria necessary. For this reason, the isolation of streptomyces species was made from sediment samples taken from the Tigris river. The Tigris River has an important place in terms of water potential and productivity. It is used for many purposes such as agricultural irrigation, drinking water supply and fishing. Elazig Hazar Lake's bottom seepage path and the length of the river fed by the Eastern Anatolian mountains is 1900 km (Budak et al., 1997; Ergun and Gürbüz, 2012). Many secondary metabolites thought to 
contribute to the productivity of the river are produced by bacteria. Actinobacteria are natural members of both terrestrial and aquatic systems (Mullowney et al., 2015). It has been determined that actinobacteria isolated from their sediments taken from aquatic environments have high antibiotic production ability (Ayari et al., 2012; Gebreyohannes et al., 2013). Today, $80 \%$ of the antibiotics used for medical purposes are produced by Streptomycetes and Micromonospora bacteria. Life cycles of Gram-positive streptomyces bacteria are quite complex. In addition, it has been determined that the antibiotics they produce have anticancer, antiparasitic and antifungal effects (Elliot et al., 2008; Law et al., 2017). The majority of Streptomyces members produce a secretion of geosmin, producing a characteristic soil odor. These bacteria have attracted attention by scientists for their potential to produce pharmaceutically important bioactive compounds and industrial enzymes (Shivlata and Tulasi, 2015; Ser et al., 2017). Streptomyces bacteria undergo physiological differentiation in a stressful environment caused by nutritional shortages and begin to produce secondary metabolites (Horinouchi, 2002). In this study, isolation and identification of 3 different Streptomyces species isolated from sediment from the Dicle region were performed. Subsequently, 16S rRNA gene sequence was obtained and the similarities and differences between species were revealed.

\section{Materials and methods Bacteria isolation}

Sediment samples were taken from different parts of the Tigris River in Diyarbakır. Dilution method was applied for the isolation of Streptomyces species. Inoculation was performed on Bennet's agar medium. Then it was incubated at $28{ }^{\circ} \mathrm{C}$ for 15 days for incubation. These colonies were transferred to Bennet's Agar medium by line planting method and colonies were dropped one by one. Isolates were stored at $-20^{\circ} \mathrm{C}$ in cryogenic tubes containing 20 \% glycerol (Seçkin and Önalan, 2020).

\section{Colorimetric differences of bacteria}

Bacteria growing on Bennet's agar medium were grown on Oatmeal Agar medium for color grouping after morphological selection. After 15 days of incubation at $27^{\circ} \mathrm{C}$, differences were determined according to color formation (Seçkin and Önalan, 2020).

\section{DNA isolation}

High molecular weight DNA was isolated with the automated QIAcube in conjunction with the Mericon Bacteria Mini kit as described by the manufacturer. Total cellular DNA concentration was determined by QIAxpert (Qiagen) (Azarova et al., 2020).

\section{Sequence analysis}

A sample sheet was prepared on the MiSeq sequencer (Illumina) to provide run details. A standard flow - cell was inserted into the flow cell chamber. The pooled sample was diluted with chilled HT1 buffer to a concentration of $2 \mathrm{nmol} / \mathrm{I}$ and an equal amount of $0.2 \mathrm{~N} \mathrm{NaOH}$ to denaturate the sample was added and incubated for five minutes. A PhiX sample at $2 \mathrm{nmol} / \mathrm{I}$ was denatured in the same way. Both the sample and the PhiX were diluted to $8 \mathrm{pmol} / \mathrm{I}$ and $1 \%$ PhiX was added to the sample. Then, $600 \mu$ of the spiked sample with a final concentration of $8 \mathrm{pmol}$ / I was pipetted into the sample well on the MiSeq consumable cartridge before loading in the cooling section of the MiSeq machine. Sequencing was performed on a MiSeq sequencer using $151 \mathrm{bp}$ paired - end reads, including an index run according to the manufacturer's instructions (Sikkema-Raddatz et al., 2013).

\section{Results}

The $\mathrm{pH}$ rates in the sampling area were measured as 7.65 and 7.70. The moisture content was measured as $59 \%$. Sediment sample and pictures of the isolates planted on Bennett's Agar in sediment samples and isolated and purified at the end of $28{ }^{\circ} \mathrm{C}$ incubation period are given below (Figure 1). 

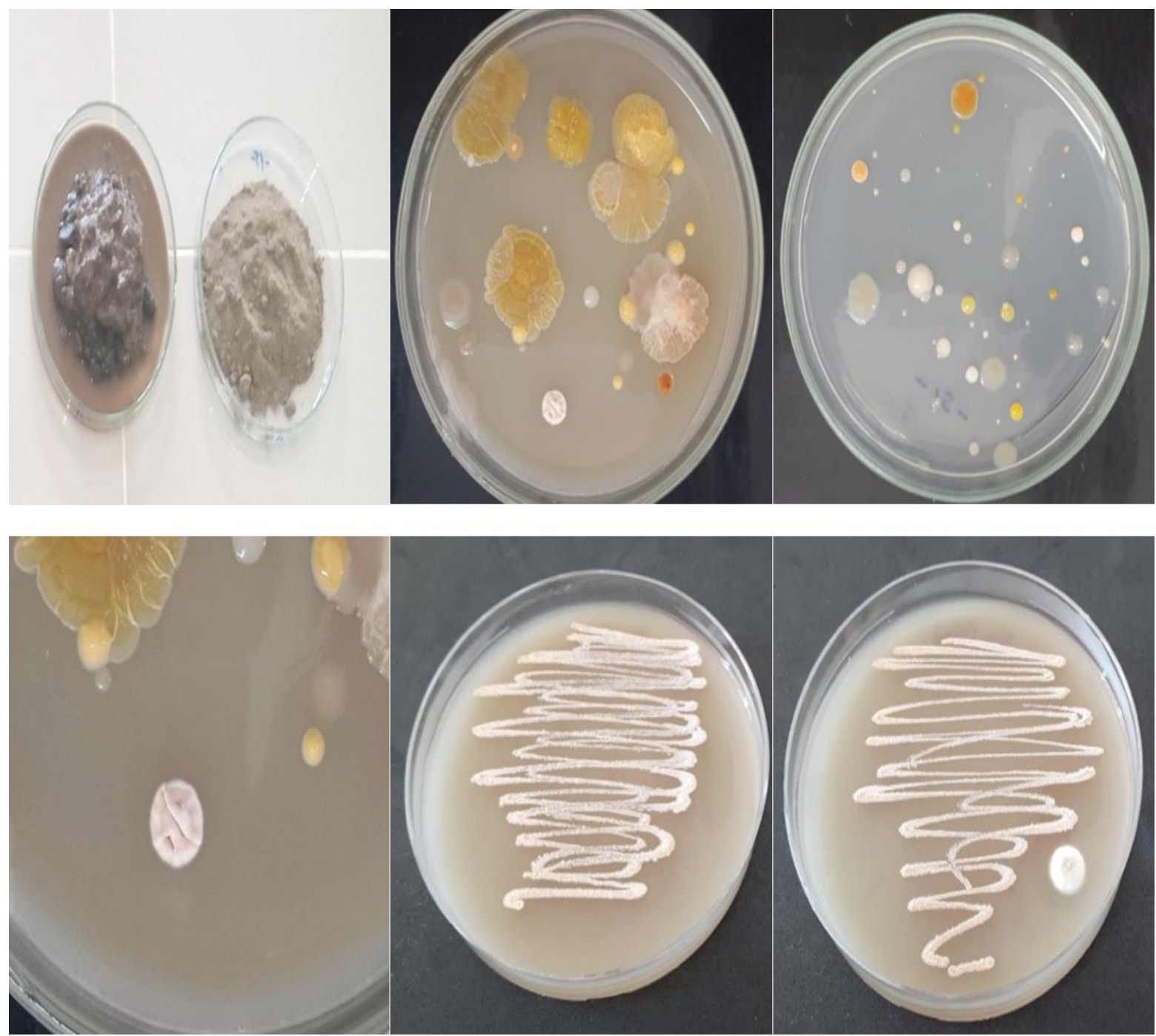

Figure 1. Streptomyces species isolated in the study growing on Bennet's agar.

Considering the spore chain morphology of the isolated Streptomyces species, it was seen that a knobby structure was formed (Figure 2).

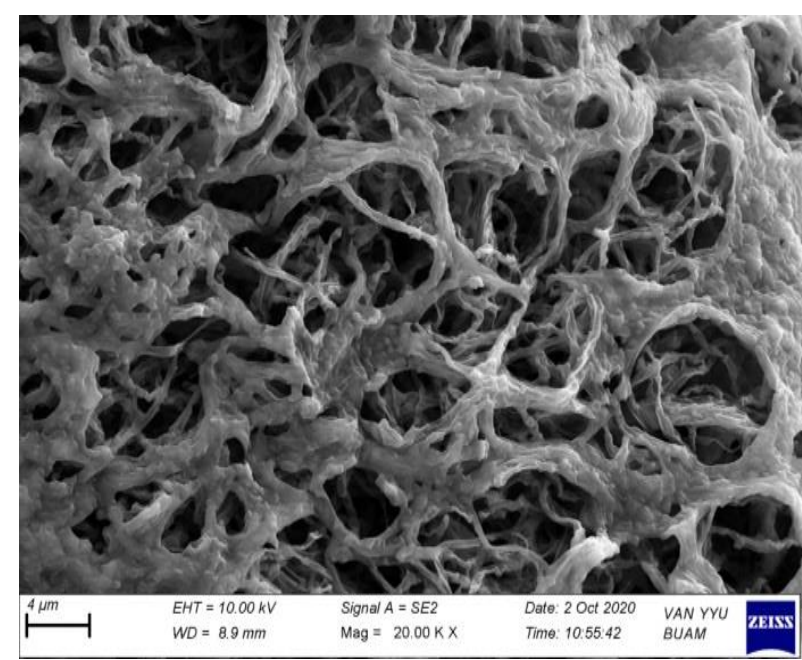

Figure 2. Electron microscope pictures of Streptomyces $\mathrm{sp}$. isolated in this study
The A260 / $280 \mathrm{~nm}$ nanospectrophotometric purity ratios of the isolated DNA were found to vary between $1.87-1.91$. The fact that the DNA purity rates of the samples are close to each other and the purity level is within a reliable range shows that the isolations made with the automatic isolation robot give healthier results.

The molecular identification of the bacterial isolates used in the study was performed by sequencing using isolated DNAs and bacterial universal primers (27F-1492R). Percent identification results of bacteria isolated according to the sequence results are given below (Table 1 ). 
Table 1. Identification results of isolated Streptomyces sp.

\begin{tabular}{|c|c|c|c|c|}
\hline İzolat No & ID & Max ID & Percent \% & *Acc number \\
\hline $1^{*}$ & Streptomyces sp. & Streptomyces tendae & 99,3 & - \\
\hline $2 *$ & Streptomyces sp. & Streptomyces tritolerans & 93,9 & - \\
\hline $3 *$ & Streptomyces sp. & Streptomyces tritolerans & 93,4 & - \\
\hline 4 & Streptomyces sp. & Streptomyces tendae strain SN4 & - & MT071712 \\
\hline 5 & Streptomyces sp. & Streptomyces sp. strain RC2 & - & MT012004 \\
\hline 6 & Streptomyces sp. & Streptomyces sp. KK9-13 & - & LC487844 \\
\hline 7 & Streptomyces sp. & Streptomyces tendae strain YBS75 & - & MH250280 \\
\hline 8 & Streptomyces sp. & Streptomyces tritolerans & - & MG334128 \\
\hline 9 & Streptomyces sp. & Streptomyces tritolerans & - & MG334126 \\
\hline 10 & Streptomyces sp. & Streptomyces collinus strain Hu001 & - & JQ689078 \\
\hline 11 & Streptomyces sp. & Streptomyces collinus strainGF37216 & - & JN107754 \\
\hline 12 & Streptomyces sp. & Streptomyces tritolerans strain LZ16-18 & - & МT990543.1 \\
\hline 13 & Streptomyces sp. & Streptomyces collinus subsp. albescens & - & AB184101 \\
\hline 14 & Streptomyces sp. & Streptomyces violaceorubidus WLD114 & - & MG856110 \\
\hline 15 & Streptomyces sp. & Streptomyces violaceorubidus strain CBS & - & MH251034 \\
\hline 16 & Streptomyces sp. & Streptomyces violaceorubidus CBS 153 & - & MH250980 \\
\hline 17 & Streptomyces sp. & Streptomyces violaceorubidus CBS 116 & - & MH250945 \\
\hline 18 & Streptomyces sp. & Streptomyces violaceorubidus CBS 112 & - & MH250941 \\
\hline
\end{tabular}

* The sequences of bacteria isolated in this study were blasted in the gene bank and sequences with $93 \%$ or more similarity to each isolate sequence were selected. 1,2 and 3th bacteria are isolated in this study. The others obtained from GenBank.

As a result of the sequence analysis, the results of the alignment analysis showing the intraspecies similarity rates of the bacteria isolated and identified in this study are given below. When performing the alignment analysis, the gap and locus gaps formed at the beginning and end of the sequences were deleted due to the difference in the number of nucleic acids read as a result of each sequence and the length of the sequence loaded into the gene bank, and alignment analysis was performed according to the sequence data of the same length. This also eliminated any similarities or differences resulting from sequence length or shortening. The cladogram showing the affinity relationship of bacteria isolated in the study with bacteria isolated from different regions in the gene bank is given below. It is seen that the same type of bacteria isolated from the same area is most similar to each other. In this study, it was observed that the bacteria isolated from the same area were closest to each other and that other isolates differed at different rates according to their similarity for their own species (Figure 3). 


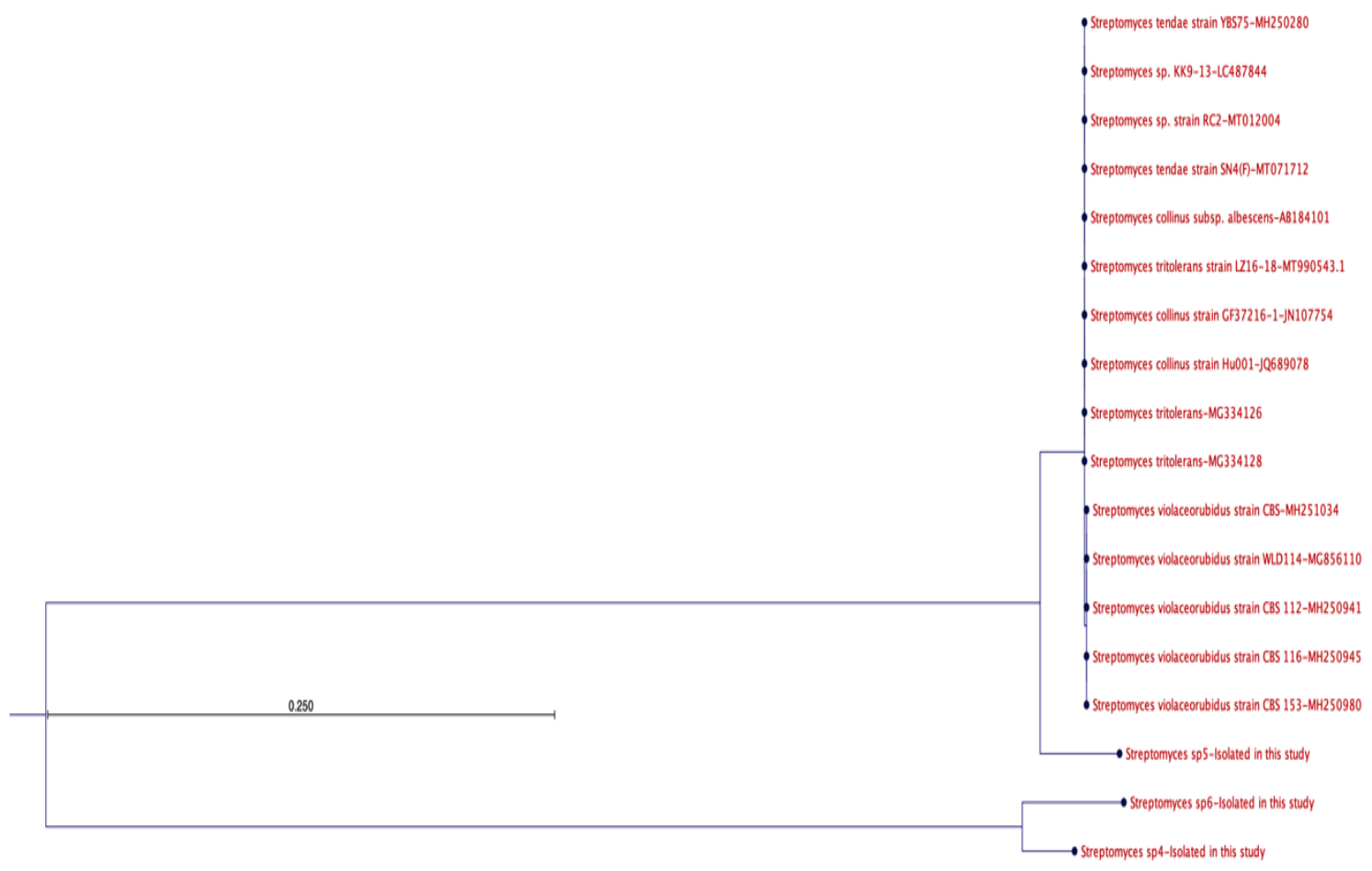

Figure 3. Dendrogram of isolated bacteria and other related sequences in GenBank

Nucleotide sequencing differences were found to be $0.3 \%$, reporting that they were isolated from different water sources. It was observed that 2 Streptomyces species isolated in

\section{Discussion}

It has been proven by many scientific studies that Streptomyces bacteria produce a large number of secondary metabolites in terms of biotechnology and health. Therefore, aquatic areas such as rivers and lakes, which have not been adequately explored, are considered to be very important for the discovery of new Streptomyces species. Looking at SEM images of Streptomyces bacteria isolated from volcanic caves, it was determined that a knotty structure was formed (Riquelme et al., 2015).

Streptomyces coelicoflavus GIAL86 bacteria were isolated from Iran Meyghan Salt Lake (Salehghamari et al., 2019). Streptomyces aburaviensis, Streptomyces gramineus and Streptomyces psammoticus species were isolated from the sediments taken from the Guaviare River (Laura et al., 2018). Sequence analysis of the $16 \mathrm{~S}$ rDNA gene region of YC537T species isolated from lake sediment collected from Bolu Yenicağa Lake was the result of Streptomyces ziwulingensis F22T (97.9 \%), Streptomyces tauricus JCM 4837 T (97.7 $\%)$ and Streptomyces beijiangensis NBRC $100044 \mathrm{~T}$ (97.6 \%) species strain (Tokatli et al., 2020). the study were different from Streptomyces species obtained from GenBank, and 1 isolate was similar.

In a different study, it was reported that Amycolatopsis nivea was isolated from the sediment sample taken from the Yellow River of China (Niu et al., 2020). In a different study, it was reported that bacterial isolation and molecular identification were carried out from sediment samples taken from different points around Iğdır Balık Lake (Seçkin and Önalan, 2020). In another study, phylogenetic analysis of $16 \mathrm{~S}$ rRNA sequence of an actinomycetes strain isolated from the marine environment of India was reported to be $100 \%$ similar to Amycolatopsis alba (Dasari and Donthireddy, 2011).

As a result of the study, 2 different types of bacteria were isolated. In the GenBank database, it was seen that the bacteria isolated were 93,9\% similar. Nucleotide sequencing differences were found to be $7 \%$, reporting that they were isolated from different water sources. Different studies are needed to determine the differences in gene levels of the same type of bacteria isolated from different sources and to determine pathogenicity and virulence characteristics among isolates. 
Conflict of Interest Statement: The authors of the article declare that there is no conflict of interest between them.

Researchers' Contribution Rate Statement Summary: The authors declare that they have contributed equally to the article.

\section{References}

Ayari, A., Morakchi, H., Djamila, K.G. 2012. Identification and antifungal activity of Streptomyces sp. S72 isolated from Lake Oubeira sediments in North-East of Algeria. African Journal of Biotechnology, 11(2): 305-311.

Azarova, I.E., Klyosova, E.Y., Kolomoets, I.I., Azarova, V.A., Ivakin, V.E. 2020. Polymorphisms of the gene encoding Cytochrome b-245 beta chain of NADPH Oxidase: Relationship with redox homeostasis markers and risk of type 2 diabetes mellitus. Russian Journal of Genetics, 56(7): 856-862.

Budak, S., Duranyıldız, i.., Yetiş, Ü. 1997. Ulusal çevre eylem plani su kaynaklari yönetimi. Devlet Su İşleri Genel Müdürlüğü. Ankara.

Dasari, V.R.R.K., Donthireddy, S.R.R. (2011). Amycolatopsis alba var. nov DVR D4, a bioactive actinomycete isolated from Indian marine environment. J Biochem Tech (2011) 3(2): 251-256.

Elliot, M.A., Buttner, M.J., Nodwell, J.R. 2008. Multicellular development in Streptomyces In: D whitworth, editors. Myxobacteria: Multicellularity and differentiation. American Society for Microbiology, 419439.

Ergun, Z., Gürbüz, A. 2012. Geomorphological, climatic and anthropogenic affects on the sediment transport amounts of the euphrates and tigris rivers. 65th Geological Congress of Turkey: Ankara, Turkey pp. 574575.

Gebreyohannes, G., Moges, F., Sahile, S., Raja, N. 2013. Isolation and characterization of potential antibiotic producing actinomycetes from water and sediments of Lake Tana, Ethiopia. Asian Pacific Journal of Tropical Biomedicine, 3(6): 426-435.

Horinouchi, S. 2002. A microbial hormone, Afactor, as a master switch for morphological differentiation and secondary metabolism in Streptomyces griseus. Frontiers in Bioscience, (7): 2045-2057.

Laura, R.R., Boghos, S.M., Maria, M.G., Luis, D. 2018. Optimization of the cytotoxic activity of three Streptomyces strains isolated from
Guaviare River sediments (Colombia, South America). BioMed Research International, doi: 10.1155/2018/2839356.

Law, J.W.F., Ser, H.L., Khan, T.M., Chuah, L.H., Pusparajah, P. 2017. The potential of Streptomyces as biocontrol agents against the rice blast fungus, Magnaporthe oryzae (Pyricularia oryzae). Frontiers in Microbiology, 8(3): 3.

Mullowney, M.W., Hwang, C.H., Newsome, A.G., Wei, X., Tanouye, U. 2015. Diazaanthracene antibiotics from a freshwaterderived actinomycete with selective antibacterial activity toward Mycobacterium tuberculosis. ACS Infectious Diseases 1 (4): 168-174.

Niu, M.M., Ming, H., Cheng, L.J., Zhao, Z.L., Ji, W.L., Li, M., Yi, B.F., Xia, T.T., Nie, G.X. (2020). 1 Amycolatopsis nivea sp. nov., isolated from a Yellow River sample. Int J Syst Evol Microbiol 2020 May;70(5):3084-3090.

Riquelme, C., Hathaway, J.J.M., Dapkevicius, M.L.N.E., Miller, A.Z., Kooser, A. 2015. Actinobacterial diversity in volcanic caves and associated geomicrobiological interactions. Frontiers in Microbiology, 6:1342.

Salehghamari, E., Nasrollahzadeh, Z., Tahmaseb, M., Amoozegar, M.A. 2019. Pectinase enzyme from Streptomyces coelicoflavus GIAL86 isolated from Meyghan Salt Lake, Arak, Iran. International Journal of Aquatic Biology, 7(2): 106-111.

Seçkin, H., Önalan, Ş. 2020. Phylogenetic diversity of nocardia sp. obtained from different water environments. Research Journal of Biology Sciences 13(2): 37-44.

Ser, H.L., Tan, L.T.H, Law, J.W.F., Chan, K.G., Duangjai, A. 2017. Focused review: cytotoxic and antioxidant potentials of mangrove-derived Streptomyces. Frontiers in Microbiology, 8(1): 2065.

Shivlata, L., Tulasi, S. 2015. Thermophilic and alkaliphilic Actinobacteria: biology and potential applications. Frontiers in Microbiology, 6(1): 1014.

Sikkema-Raddatz, B., Johansson, L.F., De-Boer, E.N., Almomani, R., Boven, L.G. 2013. Targeted next-generation sequencing can replace Sanger sequencing in clinical diagnostics. Human mutation, 34(7): 10351042.

Tokatli, A., Idil, O., Veyisoglu, A., Saygin, H., Guven, K. 2020. Streptomyces boluensis sp. nov., isolated from lake sediment. Archives of Microbiology, 202(8): 2303-2309. 